\title{
EFFECT OF DIABETES AND SYSTEMIC INFLAMMATION PARAMETERS ON THE PROGNOSIS OF BELL'S PALSY
}

\author{
Diyabet ve Sistemik Enflamasyon Parametrelerinin Bell Palsisinin Prognozuna Etkisi
}

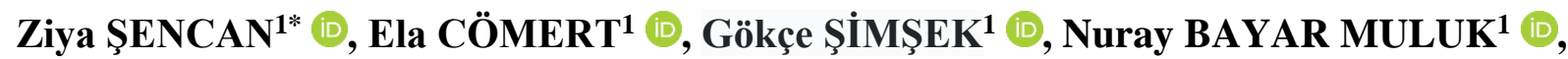 \\ Serdar Hanzala YAMAN ${ }^{1}$
}

${ }^{1}$ Kırıkkale Üniversitesi Tıp Fakültesi, KBB A.D., KIRIKKALE, TÜRKİYE

ABSTRACT

Objective: This study aimed to evaluate the prognostic importance of diabetes mellitus, hematologic and biochemical test findings including neutrophil-to-lymphocyte ratio, plateletto-lymphocyte ratio, systemic inflammation response index and triglyceride-glucose index in patients with Bell's palsy and to compare these results with healthy subjects.

Material and Methods: The study included 75 patients with incomplete Bell's palsy.

and 24 healthy subjects as the control group. Patients were divided into two groups as diabetes mellitus and non- diabetes mellitus patients. Complete blood count, biochemical tests including glucose, liver and renal function tests and blood lipid profile were analyzed from all the subjects and neutrophil-tolymphocyte ratio, platelet-to-lymphocyte ratio, systemic inflammation response index and triglyceride-glucose index values were calculated from these results.

Results: Neutrophil-to-lymphocyte ratio and systemic inflammation response index values were higher in patients with Bell's palsy when compared with the control group. Triglycerideglucose index was positively correlated with recovery time in all patients and the diabetes mellitus group. It was also positively correlated with prognosis in non- diabetes mellitus patients. High neutrophil-to-lymphocyte ratio was predictive for delayed recovery time only in non- diabetes mellitus patients.

Conclusion: Our results indicated that diabetes mellitus didn't influence severity, recovery time and prognosis of Bell's palsy. High triglyceride levels and triglyceride-glucose index values were associated with long recovery time in patients with Bell's palsy. For both diabetes mellitus and non- diabetes mellitus patients, House-Brackmann facial nerve grading scale-initial was the best parameter to predict the prognosis. Neutrophil-tolymphocyte ratio and systemic inflammation response index values were significantly higher in patients with Bell's palsy.

Keywords: Bell palsy, diabetes mellitus, inflammation, prognosis
Amaç: Bell palsili hastalarda, diyabetin prognostik önemini, nötrofil-lenfosit oran1, trombosit-lenfosit oran1, sistemik inflamasyon yanıt indeksi dahil hematolojik ve biyokimyasal test bulgularını değerlendirmek, ayrıca Bell palsili hastalarda trigliserid-glikoz indeksini değerlendirmek ve bu sonuçları sağlıklı deneklerle karşılaştırmaktır.

Gereç ve Yöntemler: Çalışmaya, Bell palsisi komplet olmayan 75 hasta ve kontrol grubu olarak 24 sağlıklı birey dahil edildi. Hastalar diyabet olan ve diyabet olmayan olarak iki gruba ayrıldı. Tüm deneklerden tam kan sayımı, glikoz, karaciğer ve böbrek fonksiyon testleri gibi biyokimyasal testler ve kan lipid profili analiz edildi ve bu sonuçlardan nötrofil-lenfosit oran1, trombosit-lenfosit oran1, sistemik inflamasyon yanıt indeksi ve trigliserid-glikoz indeksi değerleri hesaplandi.

Bulgular: Nötrofil-lenfosit oranı ve sistemik inflamasyon yanıt indeksi değerleri Bell palsili hastalarda kontrol grubuna göre daha yüksekti. Trigliserid-glikoz indeksi, tüm hastalarda ve diyabet grubunda iyileşme süresi ile pozitif korelasyon gösterdi. Trigliserid-glikoz indeksi ayrıca diyabet olmayan hastalarda prognoz ile pozitif korelasyon gösterdi. Yüksek nötrofil-lenfosit oranı, sadece diyabet olmayan hastalarda gecikmiş iyileşme süresi için öngörücüydü.

Sonuç: Sonuçlarımız, diyabetin Bell palsinin şiddetini, iyileşme süresini ve prognozunu etkilemediğini gösterdi. Nötrofil-lenfosit oranı ve sistemik inflamasyon yanıt indeksi değerleri Bell palsili hastalarda anlamlı olarak yüksekti. Yüksek trigliserid seviyeleri ve trigliserid-glikoz indeksi değerleri Bell palsili hastalarda uzun iyileşme süresi ile ilişkilendirildi. Hem diyabet hem de diyabet olmayan hastalar için, the House-Brackmann facial nerve grading scale-initial prognozu tahmin etmek için en iyi parametreydi.

Anahtar Kelimeler: Bell palsisi, diyabet, inflamasyon, prognoz 


\section{INTRODUCTION}

Bell's palsy (BP) is a rapid paresis or paralysis of the facial nerve. Facial nerve inflammation is suggested in the etiology which results in edema and compression of the nerve (1). Most of the patients recover within 3-5 months, but $29 \%$ of the patients face incomplete recovery or sequels (2). Many diseases and viral agents that progress with inflammation have been accused in etiology (3-6). Inflammation is presented as one of the main mechanisms of nerve damage (7) and the effect of systemic diseases progress with systemic inflammation on the prognosis of BP is under research $(6,8)$. Diabetes mellitus (DM) is one of these diseases which is presented as a risk factor for BP (1). Studies demonstrate the presence of low-grade inflammation in patients with DM $(9,10)$ and support the link of inflammation to the pathogenesis of DM and insulin resistance $(11,12)$. Controversy exists on the effect of DM on the recovery time and prognosis of BP (5,13-18). DM is presented as having no effect on the healing rate of $\mathrm{BP}$ in most of the studies $(5,13,16)$ whereas worse prognosis is also reported for patients with DM (18).

Triglyceride-glucose index (TyGI) is a diabetes associated metabolic index. It is presented as an accurate diagnostic tool for insulin resistance (18-21). It can be counted up from glucose and triglyceride levels from the routine biochemical analysis and can be indicative for pre-diabetic conditions (19).

Recent literature focus on the prognostic value of parameters indicating systemic inflammation for BP (22-27). The presence of systemic inflammatory response can be indicated by leukocytes, neutrophils, lymphocytes, platelets and acute-phase proteins in blood tests (28). Studies demonstrate the correlation between pre-treatment hematologic test findings and prognosis of BP (26). Many studies are performed to search the correlation between neutrophil-to-lymphocyte ratio (NLR) and platelet-to-lymphocyte ratio (PLR) and BP $(24,25,29)$. Systemic inflammation response index
(SIRI) is a new hematologic inflammatory marker based on the counts of peripheral neutrophils, monocytes and lymphocytes (28). It is used to predict the degree of inflammation in patients with cancer.

The present study aimed to evaluate the prognostic importance of DM, hematologic and biochemical test findings including NLR, PLR SIRI and TyGI in the patients with BP and to compare these results with healthy subjects.

\section{MATERIALS AND METHODS}

The study was designed as retrospective case-control study. All procedures performed in this study were complaint with the ethical standards of the institutional research committee and with the 1964 Helsinki declaration and its later amendments or comparable ethical standards. The study was approved by the local ethics committee (Kırıkkale University Ethics Committe of Non-interventional Research, date: 19.02.2020, issue number: 2020.02.16).

The study included 75 patients who were diagnosed as BP with incomplete paralysis between April 2016 and April 2019. The patients who had an additional symptom other than unilateral facial weakness, complete paralysis, any systemic disease other than DM, any medication within 1 month other than anti-DM drugs, recurrent paralysis, had a history that could predispose to facial paralysis, had less than 1 year follow-up were excluded.

Patients were divided into two groups as patients with DM and patients without DM (non-DM). The diagnosis of BP was based on BP Clinical Practice Guideline (1). The House-Brackmann facial nerve grading scale (HBG) was used to assess initial (IHBG) (at the time of diagnosing) and post-treatment (PHBG) facial nerve paralysis (30). PHBGs greater than I after 6 months was accepted as unsatisfactory recovery.

All the patients were treated with either oral or intravenous corticosteroids (methyl prednisolone 
therapy $1 \mathrm{mg} / \mathrm{kg}$ for 3 days and reduced across 10 days) within 3 days of symptom onset. The antivirus agent was not included in the treatment regimen. The patients were followed-up regularly at least 1 year from the onset of facial paralysis. Magnetic Resonance Imaging and electrodiagnostic testing were performed only in patients in whom the paralysis failed to recover in 3 months.

Since the changes depending on ethnic origin could be seen in hematological and biochemical data and normative values of SIRI and TyGI had not been established, 24 healthy subjects who had normal facial functions with no history of systemic disease and medication were included in the study to present the normative values. Informed consent was obtained from subjects who participated in the study.

Complete blood count, biochemical tests including glucose, liver and renal function tests and blood lipid profile were analyzed from all subjects and NLR, PLR, SIRI and TyGI values were calculated from these results. The data were compared between healthy subjects and patients, and DM and non-DM patients. The effect of these parameters on the severity, recovery time and prognosis of BP were explored.

\section{Statistical Analysis}

Non-parametric data were analyzed using the KruskalWallis test $(\mathrm{p}<0.05)$. The Mann-Whitney $U$ test and Bonferroni Correction test were applied in binary comparisons of groups $(\mathrm{p}<0.0167)$.

Parametric data were analyzed with One-Way Analysis of Variance (ANOVA) to evaluate the differences between groups $(\mathrm{p}<0.05)$. Tukey Multiple Comparisons test and Independent Samples $t$ test were applied in binary comparisons of groups $(p<0.016)$.

Spearman's rho Correlation test was used to determine the correlation between disease parameters specially to predict the improvement and/or prognosis $(p<0.05)$.
ROC-Curve analysis was applied to determine the sensitivity and specificity of the study parameters to predict the prognosis $(p<0.05)$.

The Likelihood-Ratio test and Logistic Regression test were applied to the variables for prediction of the "best" variable or parameter of the improvement time and prognosis $(p<0.05)$

\section{RESULTS}

Thirty-six patients (48\%) were non-DM and 39 patients $(52 \%)$ had DM. The competence of the sample size was supported by $G$ power analysis ( $\mathrm{G}^{*}$ Power, version 3.1.9.2, minimum sample size of groups $=33$, alpha $=0.05$, actual power $=0.80$ )

The average recovery time was $32.3 \pm 19.4$ days (range 7-90 days) in the non-DM group and 59.3 \pm 56.4 days (range 14-180 days) in the DM group. Total recovery occurred in $76 \%$ (57 patients) of the patients, $81 \%$ (29 patients) in the non-DM group and 72\% (28 patients) in the DM group. Among the 18 patients who presented with unsatisfactory recovery, the PHBG was grade II in 11 patients and grade III in 7 patients in 6 months follow up. No additional pathology was detected in their radiologic evaluation. None of the patients had any sequel. Results of comparison between patients and the control group are presented in Table 1.

Analysis of Patients with BP

The correlation analysis revealed positive correlations between recovery time and triglyceride level ( $\mathrm{r}=0.294$, $p=0.010)$, TyGI value $(\mathrm{r}=0.312, p=0.007)$ IHBG $(\mathrm{r}=0.388, p=0.001)$, red cell distribution width (RDW) level $(\mathrm{r}=0.252, p=0.029)$ and prognosis $(\mathrm{r}=0.242$, $p=0.036)$. Positive correlations existed between prognosis and IHBG level $(\mathrm{r}=0.392, p<0.001)$ and triglyceride level $(\mathrm{r}=0.238, p=0.040)$. IHBG level was positively correlated with alanine aminotransferase (ALT) level $(\mathrm{r}=0.291, p=0.011)$ and insulin use $(\mathrm{r}=0.265, p=0.022)$. Positive correlation existed between SIRI value and NLR $(\mathrm{r}=0.746, p<0.001)$. Triglyceride 
and IHBG levels and TyGI and RDW values could be used as the best parameters in predicting the recovery time. Besides, although they did not have a direct correlation with recovery time; age, mean platelet volume (MPV) and ALT levels were also predictive for recovery time (Table 2 ). Triglyceride level $>174 \mathrm{mg} / \mathrm{dL}$
(61\% sensitive and $70 \%$ specific, area $=0.661, p=0.041)$ and IHBG >III-IV (3.5) (61\% sensitive and 79\% specific, area $=0.759, p=0.001$ ) were predictive for poor prognosis (Figure 1). IHBG and RDW level were the best parameters to predict the prognosis (Table 2).

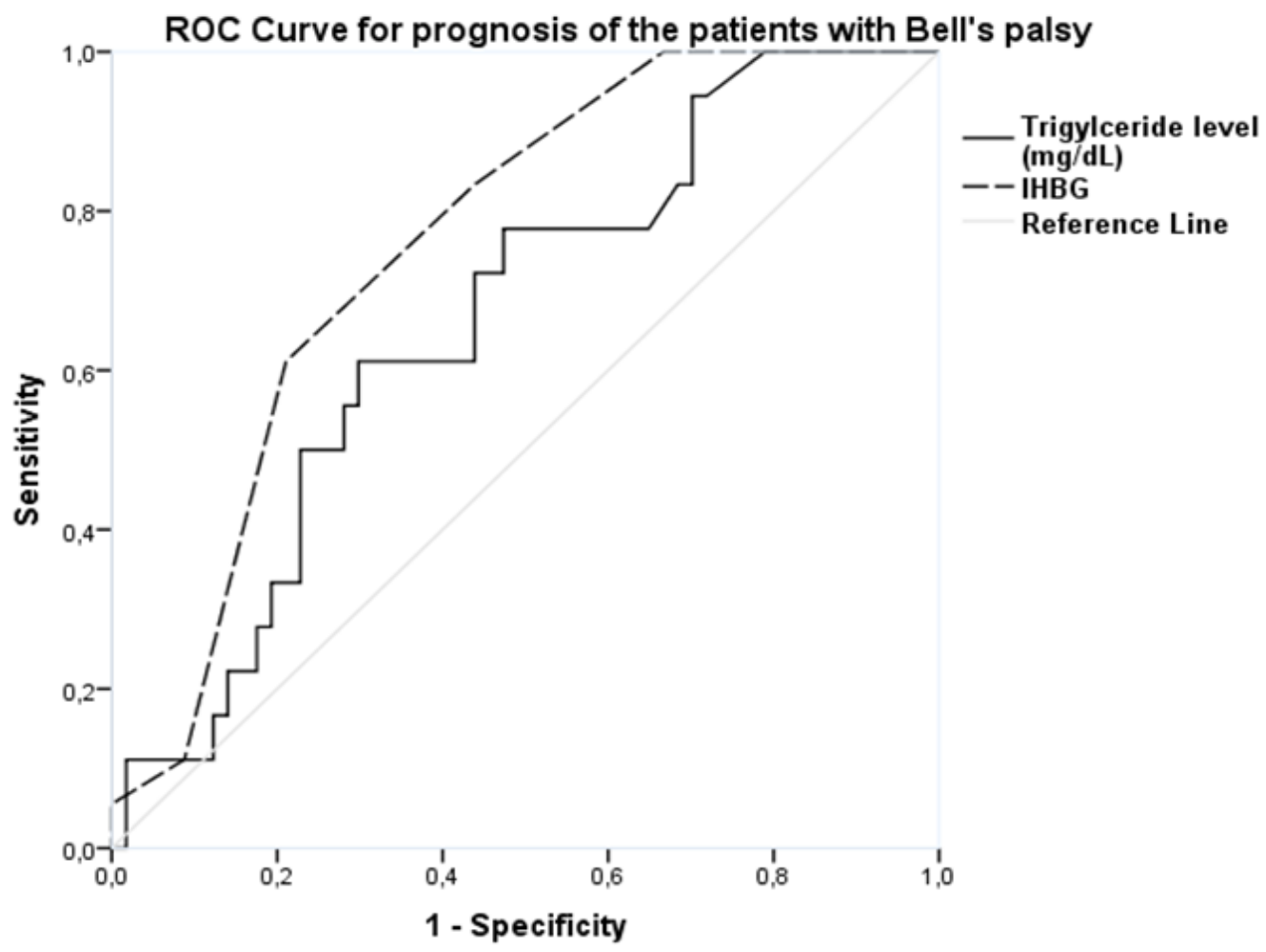

Figure 1: The ROC Curve analysis graphic demonstrating the sensitivity and specificity of the variables for prognosis of Bell's palsy. IHBG: initial House-Brackmann grade

Results of the analysis between DM and Non-DM patients are presented in Table 3.

\section{Analysis of patients with DM}

The correlation analysis revealed positive correlations between recovery time and triglyceride level $(r=0.327$, $p=0.042)$ and TyGI value $(\mathrm{r}=0.356, p=0.026)$. Positive correlations were detected between prognosis and IHBG $(\mathrm{r}=0.430, p=0.06)$, AST $(\mathrm{r}=0.381, p=0.017)$ and ALT levels $(\mathrm{r}=0.370, p=0.02)$. In addition, a positive correlation existed between IHBG and ALT level $(\mathrm{r}=0.452, p=0.004)$. Triglyceride and glucose levels, TyGI value and the use of insulin were presented as the best parameters in predicting the recovery time (Table 4). IHBG >III-IV (3.5) (81\% sensitive and $71 \%$ specific, area $=0.768, p=0.010)$ was predictive of poor prognosis (Figure 2.b). IHBG was the best parameter to predict the prognosis (Table 4). 
Table 1: The demographic data, clinical findings and laboratory results of the control and Bell's palsy groups. Independent Samples $t$ test, Mann Whitney $U$ test and Chi-S-square test $(p<0.05)$.

\begin{tabular}{|c|c|c|c|c|}
\hline & Control & Bell's palsy & & \\
\hline & Mean \pm SD/ & Mean \pm SD/ & & \\
\hline & Median (min-max)/ & Median (min-max)/ & & \\
\hline Variable & $\mathrm{n}(\%)$ & $\mathrm{n}(\%)$ & $\mathrm{t} / \mathrm{Z} / X^{2}$ & $p$ \\
\hline Age, year & $51.17 \pm 13.59$ & $53.28 \pm 17.64$ & $-0.549 *$ & 0.584 \\
\hline \multirow[t]{2}{*}{$\overline{\text { Gender }}$} & $10(10.1 \%)$ & $34(34.3 \%)$ & $0.099^{* * *}$ & 0.753 \\
\hline & $14(14.1 \%)$ & $41(41.4 \%)$ & & \\
\hline$\overline{\mathrm{MPV}}$ (fL) & $9.83 \pm 0.96$ & $9.82 \pm 1.21$ & $0.044^{*}$ & 0.965 \\
\hline RDW (\%) & $13.40(12.10-16.90)$ & $13.60(12.10-20.90)$ & $-1.447 * *$ & 0.148 \\
\hline Leukocyte (uL) & $7270(5070-15800)$ & $9810(4830-26130)$ & $-2.858 * *$ & 0.004 \\
\hline Neutrophil (uL) & $4205(2630-10330)$ & $6200(2300-23900)$ & $-3.748 * *$ & $<0.001$ \\
\hline Lymphocyte (uL) & $2225(1360-3640)$ & $2360(430-7490)$ & $-0.747 * *$ & 0.455 \\
\hline Monocyte (uL) & $400(270-770)$ & $500(10-1050)$ & $-1.650 * *$ & 0.099 \\
\hline Platelet (uL) & $266500(189000-398000)$ & $255000(72000-706000)$ & $-0.861 * *$ & 0.389 \\
\hline NLR & $1.93(1.17-6.42)$ & $2.83(0.81-32.13)$ & $-2.629 * *$ & 0.009 \\
\hline PLR & $111.97(85.52-232.75)$ & $108.07(43.21-496.819$ & $-1.208 * *$ & 0.227 \\
\hline SIRI & $727.61(361.09-4940.43)$ & $1320(64.19-17696.49)$ & $-3.344 * *$ & 0.001 \\
\hline Glucose (mg/dl) & $96(80-110)$ & $119(71-429)$ & $-4.713 * *$ & $<0.001$ \\
\hline $\begin{array}{l}\text { Triglyceride } \\
(\mathrm{mg} / \mathrm{dl})\end{array}$ & $91(50-231)$ & $132(31-554)$ & $-3.005 * *$ & 0.003 \\
\hline TyGI & $4.53 \pm 0.21$ & $4.91 \pm 0.39$ & $-4.571 *$ & $<0.001$ \\
\hline $\mathrm{LDL}(\mathrm{mg} / \mathrm{dl})$ & $108.66 \pm 30.89$ & $116.00 \pm 40.63$ & $-0.812^{*}$ & 0.419 \\
\hline HDL (mg/dl) & $51(36-71)$ & $51(10-96)$ & $-0.098 * *$ & 0.922 \\
\hline AST (U/L) & $17(11-67)$ & $18(6-52)$ & $-1.438 * *$ & 0.151 \\
\hline ALT (U/L) & $16(7-56)$ & $18(6-110)$ & $-1.558 * *$ & 0.119 \\
\hline BUN (mg/dl) & $27(15-47)$ & $30(4-88)$ & $-1.778 * *$ & 0.075 \\
\hline $\begin{array}{l}\text { Creatinine } \\
(\mathrm{mg} / \mathrm{dl})\end{array}$ & $0.79(0.59-1.25)$ & $0.75(0.45-5.18)$ & $-1.095 * *$ & 0.274 \\
\hline
\end{tabular}

$(*)$ t value (Independent Samples t test); $\left({ }^{* *}\right) \mathrm{Z}$ value (Mann Whitney U test); $\left({ }^{* * *}\right) X^{2}$ Pearson Chi-square value (Chisquare test)

SD: standard deviation; MPV: mean platelet volume; RDW: red cell distribution width; NLR: neutrophil to lymphocyte ratio; PLR: platelet to lymphocyte ratio; SIRI: systemic inflammation response index; TyGI: triglycerideglucose index; LDL: low density lipoprotein; HDL: high density lipoprotein; AST: aspartate aminotransferase; ALT: alanine aminotransferase; BUN: blood urine nitrogen 
Table 2: Results of Likelihood Ratio test and Logistic Regression test for recovery time and prognosis of Bell's palsy $(p<0.05)$.

\begin{tabular}{lll}
\hline Likelihood Ratio tests for recovery time of Bell's palsy & \\
\hline Effect & $X^{2}$ & $p$ \\
\hline Age & 25.807 & 0.027 \\
MPV (fL) & 27.124 & 0.019 \\
RDW (\%) & 27.141 & 0.018 \\
\hline Triglyceride (mg/dl) & 26.266 & 0.009 \\
TyGI & 32.203 & 0.004 \\
ALT (U/L) & 24.508 & 0.040 \\
\hline IHBG & 33.007 & 0.003
\end{tabular}

Logistic Regression test for prognosis of Bell's palsy

\begin{tabular}{llll}
\hline & B & Wald & $p$ \\
\hline RDW $(\%)$ & -1.011 & 6.477 & 0.011 \\
IHBG & 1.008 & 10.504 & 0.001 \\
\hline
\end{tabular}

$X^{2}$ chi-square value

MPV: mean platelet volume; RDW: red cell distribution width; TyGI: triglyceride-glucose index; ALT: alanine aminotransferase; IHBG: initial House-Brackmann grade

\section{Analysis of Non-DM patients}

Correlation analysis revealed positive correlation between recovery time and IHBG ( $\mathrm{r}=0.484, p=0.003)$. Positive correlations existed between prognosis and IHBG ( $\mathrm{r}=0.369, p=0.027)$, triglyceride level $(\mathrm{r}=0.352$, $p=0.035)$ and TyGI value $(\mathrm{r}=0.335, p=0.046)$. IHBG was positively correlated with triglyceride level ( $\mathrm{r}=0.338, p=0.044)$. Triglyceride level, TyGI value, NLR and HDL level were presented as the best parameters in predicting the recovery time (Table 4). Triglyceride level $>159 \mathrm{mg} / \mathrm{dL}$, (with $71 \%$ sensitivity and $76 \%$ specificity, area $=0.756, \mathrm{p}=0.038)$, IHBG $>$ II-III (2.5) (with $71 \%$ sensitivity and $73 \%$ specificity, area $=0.759, \mathrm{p}=0.036)$ and TyGI value $>4.78(71 \%$ sensitivity and $65 \%$ specificity, area $=0.744, \mathrm{p}=0.048$ ) were predictive of poor prognosis (Figure 2.a). Triglyceride level was the best parameter to predict the prognosis (Table 4). 
Table 3. The demographic data, clinical findings and laboratory results of patients with DM and non-DM. Independent Samples $t$ test, Mann Whitney $U$ test and Chi-S-square test $(p<0.05)$.

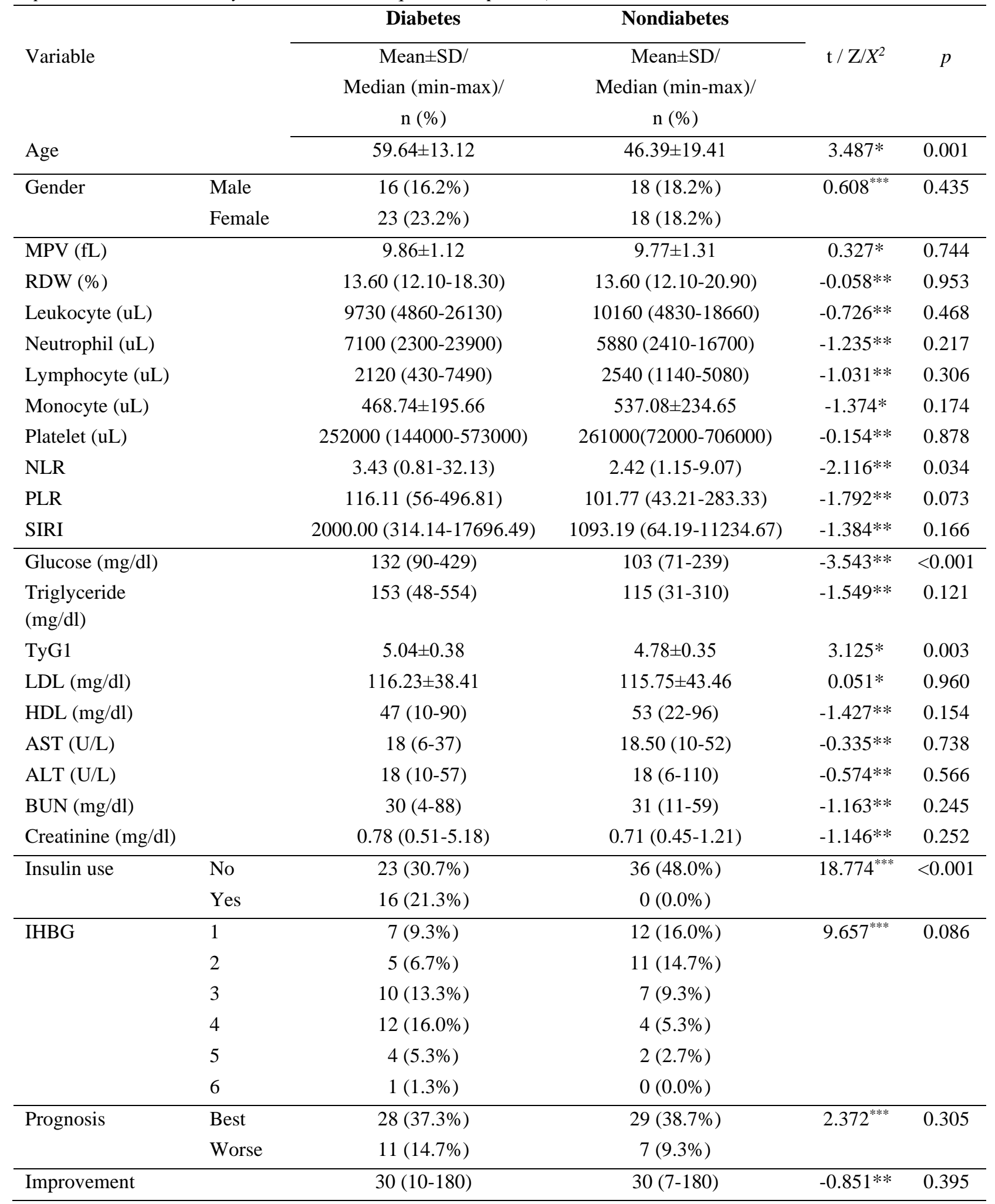

$(*) \mathrm{t}$ value (Independent Samples $\mathrm{t}$ test); $\left({ }^{* *}\right) \mathrm{Z}$ value (Mann Whitney $\mathrm{U}$ test); $\left(^{* * *}\right) X^{2}$ value (Chi- square test) SD: standard deviation; MPV: mean platelet volume; RDW: red cell distribution width; NLR: neutrophil to lymphocyte ratio; PLR: platelet to lymphocyte ratio; SIRI: systemic inflammation response index; TyGI: triglycerideglucose index; LDL: low density lipoprotein; HDL: high density lipoprotein; AST: aspartate aminotransferase; ALT: alanine aminotransferase; BUN: blood urine nitrogen; IHBG: initial House-Brackmann grade 
Table 4: Results of Likelihood Ratio test and Logistic Regression test for recovery time and prognosis of patients with $\mathrm{DM}$ and non-DM $(p<0.05)$.

\begin{tabular}{|c|c|c|c|c|}
\hline & Likelihood Ratio test for & & & \\
\hline \multirow{3}{*}{$\mathrm{DM}$} & Effect & $\overline{X^{2}}$ & & $p$ \\
\hline & Triglyceride & 51.396 & & $<0.001$ \\
\hline & TyGI & 52.617 & & $<0.001$ \\
\hline \multirow{8}{*}{ Non-DM } & Glucose & 37.557 & & $<0.001$ \\
\hline & Insuline use & 26.531 & & 0.005 \\
\hline & Triglyceride & 31.021 & & 0.001 \\
\hline & TyGI & 49.875 & & 0.037 \\
\hline & NLR & 28.767 & & 0.002 \\
\hline & HDL & 36.279 & & $<0.001$ \\
\hline & \multicolumn{4}{|c|}{ Logistic Regression test for prognosis } \\
\hline & Variable & $\mathbf{B}$ & Wald & $p$ \\
\hline $\mathrm{DM}$ & IHBG & 0.883 & 5.188 & 0.023 \\
\hline Non-DM & Triglyceride & 0.012 & 4.128 & 0.042 \\
\hline
\end{tabular}

$\mathrm{X}^{2}$ chi-square value

DM: diabetes mellitus; non-DM: non-diabetic; TyGI: triglyceride-glucose index; NLR: neutrophil to lymphocyte ratio; HDL: high density lipoprotein; IHBG: initial House-Brackmann grade
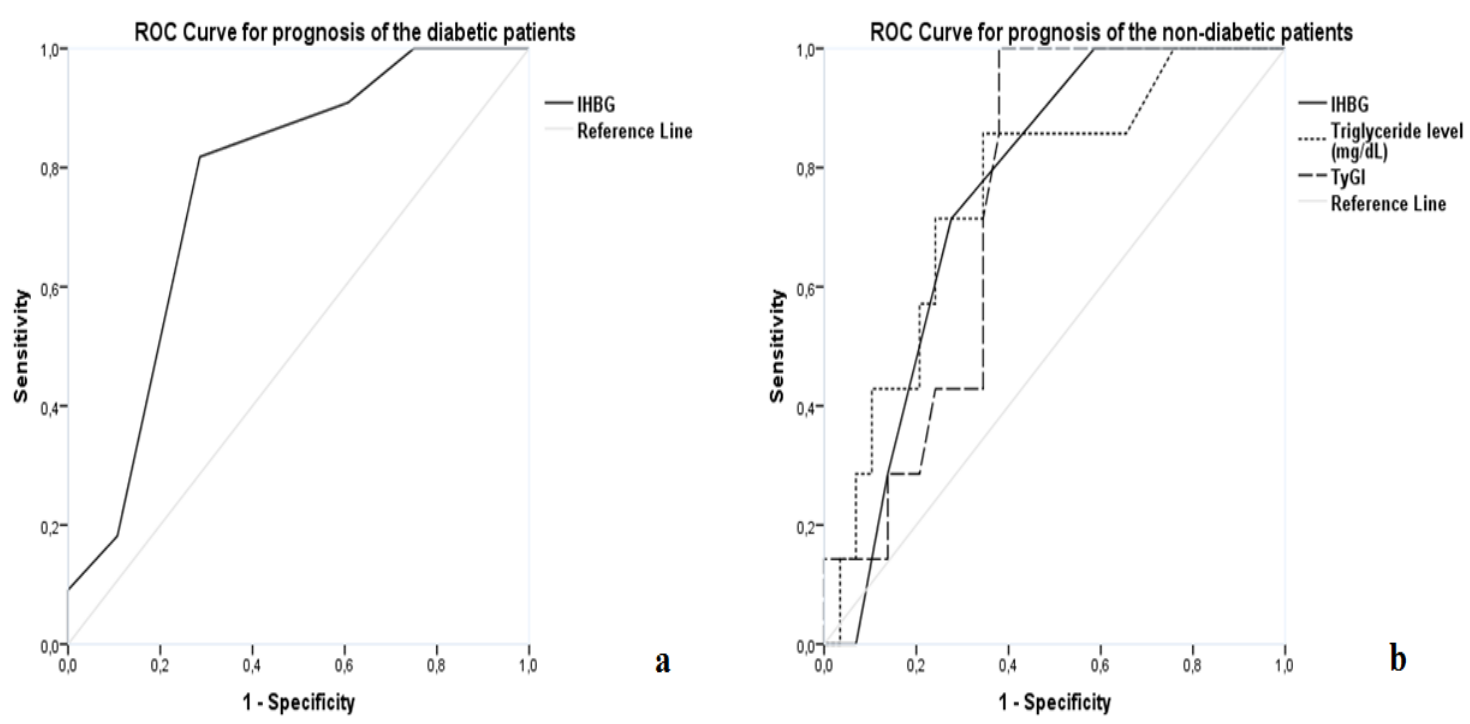

Figure 2: The ROC Curve analysis graphic demonstrating the sensitivity and specificity of the variables for prognosis of diabetic patients (2.a); and the sensitivity and specificity of the variables for prognosis of non-diabetic patients (2.b). IHBG: initial House-Brackmann grade; TyGI: triglyceride glucose index.

\section{DISCUSSION}

About $25 \%$ of the patients with BP have an associated systemic disease that can potentiate this inflammation
(31). DM is one of the systemic diseases which has been suggested as a contributor to the healing process of BP $(1,13)$. According to our results, DM patients had higher NLR and TyGI values than non-DM patients supporting 
that DM patients had a greater degree of inflammation and insulin resistance. It is generally accepted that DM does not affect prognosis of BP negatively $(5,13,15,16)$. Compatible with most of the studies in the literature, our study revealed no difference in prognosis, severity and recovery time between DM and non-DM patients.

We also investigated the effect of lipid profile and TyGI on the severity, recovery time and prognosis of BP. Previous studies detected no correlation between hypercholesterolemia and the severity of BP whereas recovery rate was reported as negatively affected by high triglyceride levels $(5,32)$. According to our results, both the triglyceride level and TyGI value had some influence on the healing of BP in both DM and non-DM patients. Patients with BP tended to have higher triglyceride levels when compared with healthy individuals, although this difference might be a result of high incidence of DM in patients' group. High triglyceride levels and TyGI values were directly associated with prolonged recovery time and triglyceride level>174 mg / dL was predictive for poor prognosis in patients with BP. High triglyceride levels and TyGI values were associated with long recovery time in both DM and non-DM patients whereas their significance on prognosis were different. In DM patients, high triglyceride levels and TyGI values did not have any influence on prognosis but in non-DM patients, triglyceride level was associated with poor prognosis. Additionally, our results revealed that a high HDL level could be predictive of short recovery time in non-DM patients.

Many inflammatory factors play role in coordinating the inflammation of the facial nerve in BP (33). Studies searched the relation of peripheral blood inflammatory markers to the prognosis and severity of BP, based on the idea that the degree of inflammation determines the severity of damage to facial nerve $(23,24)$. A recent meta-analysis reveals that not all parameters showing inflammation are significant in demonstrating the prognosis of BP (24).
Systemic inflammation is associated with poor prognosis for many inflammatory diseases $(28,29)$. SIRI was first applied to predict the survival of patients with pancreatic cancer (34). Different from NLR, the monocyte ratio is a component of SIRI, which is already presented as a prognostic parameter for Ramsey Hunt syndrome (29).

Our study revealed that the number of leukocytes and neutrophils were significantly higher in patients with BP although the values were within the normal range. NLR and SIRI values were significantly higher in patients with BP. High NLR was predictive for delayed recovery time. No association was determined between SIRI and healing in BP.

IHBG was the most constant parameter that was associated with both recovery time and prognosis in all patients with BP. IHBGs greater that III-IV and II-III were predictive of poor prognosis in DM and non-DM patients respectively. Compatible with the literature, a high RDW level was predictive for poor prognosis (22). The main drawback of our study is the relatively small sample size of our patient group. Patient selection was based on certain criteria to exclude the effect of other factors, diseases and medication to the inflammation rather than BP and DM. The competence of the sample size was supported by statistics.

Our results indicated that DM did not influence severity, recovery time and prognosis of $\mathrm{BP}$. High triglyceride levels and TyGI values were associated with long recovery time in patients with BP. For both DM and non-DM patients, IHBG was the best parameter to predict the prognosis. NLR and SIRI values were significantly higher in patients with BP and high NLR was predictive for delayed recovery time in non-DM patients. However, no association was detected between peripheral blood inflammatory markers and prognosis.

Conflict of Interest: The authors declare no potential conflicts of interest with respect to the research, authorship, and/or publication of this article. 
Support and Acknowledgment: The authors received no financial support for the research, authorship, and/or publication of this article.

Ethical Committee Approval: Kırıkkale University Ethics Committee of Non-interventional Research, date: 19.02.2020, issue number: 2020.02.16.

\section{REFERENCES}

1. Baugh RF, Basura GJ, Ishii LE, Schwartz SR, Drumheller CM, Burkholder $\mathrm{R}$ et al. Clinical practice guideline: Bell's palsy. Otolaryngol Head Neck Surg. 2013;149(3 Suppl):S1-27.

2. Peitersen E. Bell's palsy: the spontaneous course of 2,500 peripheral facial nerve palsies of different etiologies. Acta Otolaryngol Suppl. 2002;(549):430.

3. Eviston TJ, Croxson GR, Kennedy PG, Hadlock T, Krishnan AV. Bell's palsy: aetiology, clinical features and multidisciplinary care. $\mathbf{J}$ Neurol Neurosurg Psychiatry. 2015;86(12):1356-61.

4. Greco A, Gallo A, Fusconi M, Marinelli C, Macri GF, de Vincentiis M. Bell's palsy and autoimmunity. Autoimmun Rev. 2012;12(2):323-8.

5. Riga M, Kefalidis G, Danielides V. The role of diabetes mellitus in the clinical presentation and prognosis of Bell palsy. J Am Board Fam Med. 2012;25(6):819-26.

6. Liou LS, Chang CY, Chen HJ, Tseng CH, Chen CY, Sung FC. Increased risk of peripheral arterial occlusive disease in patients with Bell's palsy using population data. PLoS One. 2017;12(12):e0188982.

7. Zhang W, Xu L, Luo T, Wu F, Zhao B, Li X. The etiology of Bell's palsy: a review. J Neurol. 2020;267(7):1896-905.

8. Chweya CM, Anzalone CL, Driscoll CLW, Lane JI, Carlson ML. For whom the Bell's toll: Recurrent facial nerve paralysis, a retrospective study and systematic review of the literature. Otol Neurotol. 2019;40(4):517-28.
9. Pitsavos C, Tampourlou M, Panagiotakos DB, et al. Association between low-grade systemic inflammation and type 2 diabetes mellitus among men and women from the ATTICA Study. Rev Diabet Stud. 2007;4(2):98-104.

10. Tsalamandris S, Antonopoulos AS, Oikonomou E, Papamikroulis GA, Vogiatzi G, Papaioannou S et al. The Role of inflammation in diabetes: current concepts and future perspectives. Eur Cardiol. 2019;14(1):50-59.

11. Schmidt MI, Duncan BB, Sharrett AR, Lindberg G, Savage PJ, Offenbacher $S$ et al. Markers of inflammation and prediction of diabetes mellitus in adults (Atherosclerosis Risk in Communities study): a cohort study. Lancet. 1999;353(9165):1649-52.

12. Shoelson SE, Lee J, Goldfine AB. Inflammation and insulin resistance. J Clin Invest. 2006;116(7):1793801.

13. Şevik ES, Erdem D. Does type 2 diabetes mellitus affect the healing of bell's palsy in adults? Can $\mathbf{J}$ Diabetes. 2018;42(4):433-6.

14. Cai Z, Li H, Wang X, Niu X, Ni P, Zhang W et al. Prognostic factors of Bell's palsy and Ramsay Hunt syndrome. Medicine (Baltimore). 2017;96(2):e5898.

15. Lee HY, Byun JY, Park MS, Yeo SG. Effect of aging on the prognosis of Bell's palsy. Otol Neurotol. 2013;34(4):766-70.

16. Fujiwara T, Hato N, Gyo K, Yanagihara N. Prognostic factors of Bell's palsy: prospective patient collected observational study. Eur Arch Otorhinolaryngol. 2014;271(7):1891-5.

17. Kanazawa A, Haginomori S, Takamaki A, Nonaka R, Araki M, Takenaka H. Prognosis for Bell's palsy: a comparison of diabetic and nondiabetic patients. Acta Otolaryngol. 2007;127(8):888-91.

18. Guerrero-Romero F, Simental-Mendía LE, González-Ortiz M, Martínez-Abundis E, RamosZavala MG, Hernández-González SO et al. The product of triglycerides and glucose, a simple measure of insulin sensitivity. Comparison with the 
euglycemic-hyperinsulinemic clamp. J Clin

Endocrinol Metab. 2010;95(7):3347-51.

19. Simental-Mendía LE, Rodríguez-Morán M, Guerrero-Romero F. The product of fasting glucose and triglycerides as surrogate for identifying insulin resistance in apparently healthy subjects. Metab Syndr Relat Disord. 2008;6(4):299-304.

20. Simental-Mendía LE， Hernández-Ronquillo G, Gómez-Díaz R, Rodríguez-Morán M, GuerreroRomero F. The triglycerides and glucose index is associated with cardiovascular risk factors in normal-weight children and adolescents. Pediatr Res. 2017;82(6):920-5.

21. Unger G, Benozzi SF, Perruzza F, Pennacchiotti GL. Triglycerides and glucose index: a useful indicator of insulin resistance. Endocrinol Nutr. 2014;61(10):533-40.

22. Horibe Y, Tanigawa T, Shibata R, Nonoyama H, Kano F, Yamaguchi S et al. Efficacy of the red blood cell distribution width for predicting the prognosis of Bell palsy: a pilot study. Eur Arch Otorhinolaryngol. 2017;274(5):2303-6.

23. Kim HS, Jung J, Dong SH, Kim SH, Jung SY, Yeo SG. Association between high neutrophil to lymphocyte ratio and delayed recovery from Bell's Palsy. Clin Exp Otorhinolaryngol. 2019;12(3):2616.

24. Oya R, Takenaka Y, Imai T, Sato T, Oshima K, Ohta Y et al. Neutrophil-to-lymphocyte ratio and plateletto-lymphocyte ratio as prognostic hematologic markers of Bell's palsy: A Meta-analysis. Otol Neurotol. 2019;40(5):681-7.

25. Bucak A, Ulu S, Oruc S, Yucedag F, Tekin MS, Karakaya F et al. Neutrophil-to-lymphocyte ratio as a novel-potential marker for predicting prognosis of Bell palsy. Laryngoscope. 2014;124(7):1678-81.

26. Wasano K, Kawasaki T, Yamamoto S, Tomisato S, Shinden $\mathrm{S}$, Ishikawa $\mathrm{T}$ et al. Pretreatment hematologic findings as novel predictive markers for facial Palsy prognosis. Otolaryngol Head Neck Surg. 2016;155(4):581-7.

27. Eryilmaz A, Basal Y, Tosun A, Kurt Omurlu I, Basak S. The neutrophil to lymphocyte ratios of our pediatric patients with Bell's palsy. Int J Pediatr Otorhinolaryngol. 2015;79(12):2374-7.

28. Geng Y, Zhu D, Wu C, Wu J, Wang Q, Li R et al. A novel systemic inflammation response index (SIRI) for predicting postoperative survival of patients with esophageal squamous cell carcinoma. Int Immunopharmacol. 2018;65:503-10.

29. Wasano K, Ishikawa T, Kawasaki T, Yamamoto S, Tomisato S, Shinden S et al. Novel pre-therapeutic scoring system using patient and haematological data to predict facial palsy prognosis. Clin Otolaryngol. 2017;42(6):1224-8.

30. Engström M, Jonsson L, Grindlund M, Stålberg E. House-Brackmann and Yanagihara grading scores in relation to electroneurographic results in the time course of Bell's palsy. Acta Otolaryngol. 1998;118(6):783-9.

31. Devriese PP, Schumacher T, Scheide A, de Jongh RH, Houtkooper JM. Incidence, prognosis and recovery of Bell's palsy. A survey of about 1000 patients (1974-1983). Clin Otolaryngol Allied Sci. 1990;15(1):15-27.

32. Jung SY, Jung J, Byun JY, Park MS, Kim SH, Yeo SG. The effect of metabolic syndrome on Bell's palsy recovery rate. Acta Otolaryngol. 2018;138(7):670-4.

33. Liu W, Fan Z, Han Y, Xu L, Wang M, Zhang D et al. Activation of NF- $\mathrm{B}$ signaling pathway in HSV1-induced mouse facial palsy: Possible relation to therapeutic effect of glucocorticoids. Neuroscience. 2015;289:251-61.

34. Qi Q, Zhuang L, Shen Y, Geng Y, Yu S, Chen H et al. A novel systemic inflammation response index (SIRI) for predicting the survival of patients with pancreatic cancer after chemotherapy. Cancer. 2016;122(14):2158-67. 